\title{
Calcium, magnesium and potassium in mineral soils from the southern half of Finland
}

\author{
ARMi KaILA \\ University of Helsinki, Department of Agricultural Chemistry
}

Received February 16, 1973

\begin{abstract}
Finland with mainly an acid precambrian bedrock, were analysed for the total contents of $\mathrm{Ca}, \mathrm{Mg}$ and $\mathrm{K}$, and for the portion of these nutrients which could be exchanged by $\mathrm{N} \mathrm{NH}_{4} \mathrm{OAc}(\mathrm{pH} 7)$, dissolved by $0.1 \mathrm{~N} \mathrm{HCl}$ at room temperature, or released by $\mathrm{N} \mathrm{HCl}$ at $50^{\circ} \mathrm{C}$.

The total content of $\mathrm{Ca}$ was lowest in samples of heavy clay, $0.78 \pm 0.14 \%$ in the surface soils and $0.92 \pm 0.10 \%$ in the deeper layers. The mean content in the groups of other soils was at least about $1.1 \%$. The total content of $\mathrm{Mg}$ increased with an increase in the clay content $\left(r=0.81^{* * *}\right)$. It ranged from $0.6 \pm 0.1 \%$ in the sand and fine sand samples to $1.53 \pm 0.19 \%$ in the heavy clay soils of the surface layers and to $1.89 \pm 0.12 \%$ in those of the deeper layers. Also in the groups of loam and silt soils and of the coarser clay soils, respectively, the $\mathrm{Mg}$ content was in the deeper layers higher than in the surface soils.

The total content of $\mathrm{K}$ also increased with the clay content $\left(\mathrm{r}=0.73^{* * *}\right)$ from $1.7 \pm$ $0.1 \%$ in the sand and fine sand soils to $2.74 \pm 0.21 \%$ in the heavy clay soils of the surface layers and to $3.10 \pm 0.07 \%$ in those of the deeper layers.

The portion of exchangeable Ca was relatively high: in the groups of surface soils from more than one tenth to one third of the total amount. The corresponding average amounts released by even the more drastic treatment with acid were not markedly higher. Only a few per cents of total $\mathrm{Mg}$ were exchangeable and slightly higher amounts were dissolved by $0.1 \mathrm{~N} \mathrm{HCl}$, whereas the treatment with $\mathrm{N} \mathrm{HCl}$ at $50^{\circ} \mathrm{C}$ released about half of the total $\mathrm{Mg}$. Exchangeable $\mathrm{K}$ and $\mathrm{K}$ dissolved by $0.1 \mathrm{~N} \mathrm{HCl}$ did not exceed $1 \%$ of the total $\mathrm{K}$, except slightly in the heavy clay soils; the average amounts released by $\mathrm{N} \mathrm{HCl}$ ranged from 5 to $18 \%$ of the total $\mathrm{K}$.

The plant availability of these nutrients was discussed.
\end{abstract}

In a previous work (KAILA and RYTI 1968), characteristic differences in the total contents of $\mathrm{Ca}, \mathrm{Mg}$ and $\mathrm{K}$ in various particle size fractions of some Finnish mineral soils were found. In all the 30 samples analysed, the Ca content was in the clay fraction $(<2 \mu \mathrm{m})$ distinctly lower than in the silt $(2-20 \mu \mathrm{m})$ and fine sand $(20-200 \mu \mathrm{m})$ fractions. The clay fraction again, was richest and the fine sand fraction poorest in total $\mathrm{Mg}$. The $\mathrm{K}$ content varied in a way similar to that of $\mathrm{Mg}$ but differences between these three fractions were less marked. If this observation, which in respect to $\mathrm{Ca}$ seems 
to be contrary to most results from other countries, would be generally valid in Finland, it would mean that our soils rich in clay would be poorer in total $\mathrm{Ca}$ and richer in total $\mathrm{K}$ and, particularly, in total $\mathrm{Mg}$ than those of a coarser texture.

In order to test this assumption, a larger material of various kinds of mineral soils from the southern half of Finland were analysed for their total contents of $\mathrm{Ca}, \mathrm{Mg}$ and $\mathrm{K}$. More information about the occurrence of these nutrients was tried to get by comparing the portions exchangeable by ammonium acetate and the portions released by extraction with dilute mineral acid or by a more drastic treatment with acid at a higher temperature.

\section{Material and methods}

The material consists of 210 samples of mineral soils collected from various places in the southern half of Finland (between $60^{\circ}$ and $65^{\circ}$ ). There were 82 samples from the plough layer and 76 samples from the depths of $20 \mathrm{~cm}$ to $70 \mathrm{~cm}$ of cultivated lands, and 20 samples from the surface layer and 32 samples from the deeper layers of virgin lands. With very few exceptions the samples originated from areas with a bedrock of granite, granodiorite, migmatite, quartz feldspar schist or mica gneiss.

The samples were air-dried at room temperature and crushed to pass a $2 \mathrm{~mm}$ screen. The mechanical analysis was performed by a pipette method, the content of organic $\mathrm{C}$ was estimated by wet combustion and the $\mathrm{pH}$-values measured in $0.02 \mathrm{~N} \mathrm{CaCl}_{2}$-suspension with the ratio of soil to solution of 1 to 2.5 .

Sodium carbonate fusing was used for the determination of the total contents of $\mathrm{Ca}, \mathrm{Mg}$ and $\mathrm{K}$. Exchangeable cations were extracted by washing with $\mathrm{N}$ ammonium acetate at $\mathrm{pH}$ 7. The amounts of $\mathrm{Ca}, \mathrm{Mg}$ and $\mathrm{K}$ which would represent easily acid-soluble part of these nutrients were extracted by shaking $10 \mathrm{~g}$ of soil in $100 \mathrm{ml}$ of $0.1 \mathrm{~N} \mathrm{HCl}$ for one hour, and the more drastic treatment was the procedure developed by Schachtschabel (1961) for the determination of reserve $\mathrm{K}: 5 \mathrm{~g}$ of soil was treated with $50 \mathrm{ml}$ of $\mathrm{N} \mathrm{HCl}$ at $50^{\circ} \mathrm{C}$ for 20 hours.

The determination of $\mathrm{Ca}$ and $\mathrm{Mg}$ in the extracts was performed by Perkin Elmer atomic absorption spectrophotometer 290 and that of $\mathrm{K}$ by an EEL flame photometer.

\section{Results}

Because of the rather low number of samples in some of the textural classes, no statistically significant differences in the analytical results were found between the sand and fine sand soils, between the silt and loam soils, and between the clay loam, sandy clay and silty clay samples. Therefore, these groups of soil samples were pooled, respectively. In tables 1 to 4 , the sand and fine sand soils are samples containing more than $50 \%$ particles larger than $0.02 \mathrm{~mm}$ in diameter, silt and loam soils are composed of at least $20 \%$ the fraction $0.02-0.002 \mathrm{~mm}$ and of not more than $50 \%$ the fraction $0.2-$ 
$0.02 \mathrm{~mm}$, all with less than $30 \%$ clay $(<0.002 \mathrm{~mm})$. The group of coarser clays contains 30 to $60 \%$ clay, and the heavy clay soils are characterized by more than $60 \%$ clay.

Table 1. Contents of clay, organic $\mathrm{C}, \mathrm{Ca}, \mathrm{Mg}$ and $\mathrm{K}$ in groups of soil samples (Mean values with the confidence limits at 95 per cent level)

\begin{tabular}{|c|c|c|c|c|c|}
\hline $\begin{array}{l}\text { Number } \\
\text { of } \\
\text { samples }\end{array}$ & Clay \% & Org. C \% & Tot. Ca \% & Tot. $\mathrm{Mg} \%$ & Tot. $\mathrm{K} \%$ \\
\hline \multicolumn{6}{|l|}{ Surface soils } \\
\hline Sand, fine sand ...... 30 & $11 \pm 3$ & $3.8 \pm 0.7$ & $1.10 \pm 0.10$ & $0.56 \pm 0.08$ & $1.73 \pm 0.14$ \\
\hline Loam, silt ........... 28 & $20 \pm 2$ & $3.3 \pm 0.5$ & $1.09 \pm 0.09$ & $0.79 \pm 0.09$ & $2.18 \pm 0.11$ \\
\hline Coarser clay .......... 31 & $39 \pm 3$ & $3.8 \pm 0.5$ & $1.08 \pm 0.07$ & $1.03 \pm 0.10$ & $2.43 \pm 0.13$ \\
\hline Heavy clay ........... 13 & $70 \pm 4$ & $3.3 \pm 0.9$ & $0.78 \pm 0.14$ & $1.53 \pm 0.19$ & $2.74 \pm 0.21$ \\
\hline \multicolumn{6}{|l|}{ Deeper layers } \\
\hline Sand, fine sand ...... 28 & $6 \pm 2$ & $0.9 \pm 0.3$ & $1.10 \pm 0.13$ & $0.57 \pm 0.09$ & $1.72 \pm 0.15$ \\
\hline Loam, silt ........... 29 & $21 \pm 2$ & $0.9 \pm 0.4$ & $1.22 \pm 0.13$ & $1.04 \pm 0.11$ & $2.45 \pm 0.12$ \\
\hline Coarser clay .......... 29 & $41 \pm 3$ & $1.0 \pm 0.3$ & $1.14 \pm 0.11$ & $1.36 \pm 0.11$ & $2.84 \pm 0.09$ \\
\hline Heavy clay .......... 22 & $76 \pm 4$ & $0.7 \pm 0.1$ & $0.92 \pm 0.10$ & $1.89 \pm 0.12$ & $3.10 \pm 0.07$ \\
\hline
\end{tabular}

Data in Table 1 show that pooling the samples in this way resulted in groups with a mean clay content of about $10,20,40$ or at least $70 \%$ both in the samples of surface soils and those from the deeper layers. There is no significant difference in the mean content of organic $\mathrm{C}$ between the groups of surface soils, on the one hand, or between those from the deeper layers, on the other hand. The $\mathrm{pH}$-values not recorded in this table ranged from $\mathrm{pH} 3.9$ to $\mathrm{pH} 7.0$ with an average of about $\mathrm{pH} 5.2-5.4$ in all the groups.

The total content of $\mathrm{Ca}$ was exceptionally low in a sand soil from Satakunta, from an area with the bedrock of sandstone: $0.38 \%$ in the sample of plough layer and $0.28 \%$ in the subsoil. Without these samples the average content of total $\mathrm{Ca}$ in sand and fine sand soil was $1.12 \pm 0.09 \%$ in the surface soils and $1.13 \pm 0.12 \%$ in the deeper layers, ranging in both groups from 0.7 to $1.6 \%$. In the samples of heavy clay the lowest content of total Ca was about $0.5 \%$ and the highest $1.3 \%$. In the other groups the minimum content was about $0.7 \%$ or $0.8 \%$ and the maximum contents almost $1.9 \%$. Also the average content of total $\mathrm{Ca}$ tends to be in the heavy clay soils lower than in those of a coarser texture.

On the basis of the mean values, the total content of $\mathrm{Mg}$ distinctly increases within the surface soils and within the samples from the deeper layers with the increase in the clay content. Except in the sand and fine sand soils, the surface soils seem to be somewhat poorer in $\mathrm{Mg}$ than the corresponding group of the samples from deeper layers. The lowest contents, about $0.2 \% \mathrm{Mg}$, were found in several virgin or cultivated sand or fine sand soils, and the highest results among these soils were about $1.1 \%$. In the samples of heavy clay soils the content of total $\mathrm{Mg}$ varied from 1.0 
to $2.1 \%$ in the surface samples and from 1.3 to $2.3 \%$ in the subsoil samples. The minimum values of the other groups were distinctly higher than that of the sand and fine sand soils and their maximum value was markedly lower than that of the heavy clay samples.

The average content of total $\mathrm{K}$ also increases with the increase in the clay from group to group, although in the surface samples the difference between the $\mathrm{K}$ contents of coarser clay and heavy clay soils is not statistically significant because of the large variation and the small number of samples. There is no difference between the mean $\mathrm{K}$ content of sand and fine sand soils from the surface layer and from the subsoil, but in all the other groups the surface soils tend to be somewhat lower in total $\mathrm{K}$. The lowest value was found for a virgin fine sand soil, $0.8 \% \mathrm{~K}$, and the highest for a heavy clay sample from the depth of 50 to $60 \mathrm{~cm} 3.4 \% \mathrm{~K}$.

In all these 210 samples, the mean content of total $\mathrm{Ca}$ is $1.08 \pm 0.04 \%$, that of total $\mathrm{Mg} 1.04 \pm 0.07 \%$, and that of total $\mathrm{K} 2.35 \pm 0.07 \%$. In the 95 samples of clay soils the average $\mathrm{Ca}$ content is $1.02 \pm 0.05 \%$, in the 115 non-clay samples it tends to be somewhat higher, $1.13 \pm 0.05 \%$. The mean content of total $\mathrm{Mg}$ in clay soils, $1.40 \pm 0.09 \%$, is distinctly higher than that in the non-clay soils, $0.74 \pm 0.06 \%$. Also the mean content of total $\mathrm{K}$ in the clay soils, $2.75 \pm 0.08 \%$, is significantly higher than that in the nonclay samples, $2.20 \pm 0.09 \%$.

The dependence of the total content of $\mathrm{Mg}$ on the clay content of all samples is also proved by the total linear correlation coefficients between these variables which is $r=0.81^{* * *}$. The correlation coefficient for the relationship between the total $\mathrm{K}$ and clay contents is somewhat lower, or $\mathrm{r}=0.73^{* * *}$. On the other hand, a low but significant negative relationship between the contents of $\mathrm{Ca}$ and clay is indicated by the correlation coefficient $\mathrm{r}=-0.32^{* * *}$. In the 95 samples of clay soils this relationship seems to be somewhat closer with $\mathrm{r}=-0.48^{* * *}$.

In each group of the soil samples (Table 2) the mean content of exchangeable $\mathrm{Ca}$ is markedly higher than that of $\mathrm{Mg}$ or $\mathrm{K}$, and it also represents a considerably larger portion of the total content than do the exchangeable form of the other two cations. In some heavy clay samples about one half of the total $\mathrm{Ca}$ was found to be exchangeable by $\mathrm{N} \mathrm{NH}_{4} \mathrm{OAc}$, while not more than about one tenth of the total $\mathrm{Mg}$ and less than $2 \%$ of the total $\mathrm{K}$ were exchangeable. On the other hand, in some of the sand and fine sand samples of the deeper layers only $0.1 \%$ of total $\mathrm{Ca}$ and $0.02 \%$ of total $\mathrm{Mg}$ or $\mathrm{K}$ were exchangeable. Both the amount of these cations as $\mathrm{mg} / 100 \mathrm{~g}$ of soil and the portions they represent of the total contents tend to increase from non-clay soils to clay soils more distinctly within the samples of deeper layers than within those of the surface soils with their higher content of organic exchangers. The results in Table 2 show no significant difference between the heavy clay samples from the topsoils and subsoils. In the other groups, the mean contents of exchangeable $\mathrm{Ca}$ and $\mathrm{K}$ and also their percentage of the total contents are higher in the surface soils. This is the case with $\mathrm{Mg}$ only in the sand and fine sand soils. 
Table 2. Exchangeable $\mathrm{Ca}, \mathrm{Mg}$, and $\mathrm{K}$ in groups of soil samples (Mean values with the confidencelimits at 95 per cent level)

\begin{tabular}{|c|c|c|c|c|c|c|}
\hline & $\mathrm{Ca}$ & $\mathrm{Mg}$ & $\mathrm{K}$ & $\mathrm{Ca}$ & $\mathrm{Mg}$ & $\mathrm{K}$ \\
\hline & \multicolumn{3}{|c|}{$\mathrm{mg} / 100 \mathrm{~g}$} & \multicolumn{3}{|c|}{$\%$ of total } \\
\hline \multicolumn{7}{|l|}{ Surface soils } \\
\hline Sand, fine sand .... & $143 \pm 33$ & $13 \pm 3$ & $16 \pm 3$ & $13.4 \pm 3.0$ & $2.3 \pm 0.6$ & $1.0 \pm 0.2$ \\
\hline Loam, silt ............ & $154 \pm 29$ & $17 \pm 4$ & $15 \pm 5$ & $14.2 \pm 2.4$ & $2.3 \pm 0.5$ & $0.7 \pm 0.2$ \\
\hline Coarser clay .......... & $208 \pm 29$ & $27 \pm 5$ & $25 \pm 4$ & $19.9 \pm 3.1$ & $2.8 \pm 0.6$ & $1.0 \pm 0.2$ \\
\hline Heavy clay .......... & $257 \pm 42$ & $84 \pm 15$ & $32 \pm 5$ & $34.7 \pm 5.7$ & $5.9 \pm 1.5$ & $1.2 \pm 0.2$ \\
\hline \multicolumn{7}{|l|}{ Deeper layers } \\
\hline Sand, fine sand .... & $18 \pm 6$ & $2 \pm 1$ & $5 \pm 2$ & $1.8 \pm 0.6$ & $0.5 \pm 0.2$ & $0.3 \pm 0.2$ \\
\hline Loam, silt ............ & $74 \pm 18$ & $19 \pm 5$ & $8 \pm 2$ & $6.3 \pm 1.3$ & $1.9 \pm 0.5$ & $0.3 \pm 0.1$ \\
\hline Coarser clay ......... & $136 \pm 25$ & $49 \pm 4$ & $14 \pm 3$ & $12.4 \pm 2.6$ & $3.6 \pm 0.9$ & $0.5 \pm 1.0$ \\
\hline Heavy clay .......... & $249 \pm 31$ & $98 \pm 28$ & $32 \pm 5$ & $28.5 \pm 4.6$ & $5.2 \pm 1.4$ & $1.0 \pm 0.1$ \\
\hline
\end{tabular}

Table 3. $\mathrm{Ca}, \mathrm{Mg}$, and $\mathrm{K}$ extracted by $0.1 \mathrm{n} \mathrm{HCl}$ at $20^{\circ} \mathrm{C}$

(Mean values with the confidence limits at 95 per cent level)

\begin{tabular}{|c|c|c|c|c|c|c|}
\hline & $\mathrm{Ca}$ & $\mathrm{Mg}$ & $\mathbf{K}$ & $\mathrm{Ca}$ & $\mathrm{Mg}$ & $\mathrm{K}$ \\
\hline & \multicolumn{3}{|c|}{$\mathrm{mg} / 100 \mathrm{~g}$} & \multicolumn{3}{|c|}{$\%$ of total } \\
\hline \multicolumn{7}{|l|}{ Surface soils } \\
\hline Sand, fine sand .... & $180 \pm 39$ & $14 \pm 4$ & $16 \pm 3$ & $16.9 \pm 3.6$ & $2.6 \pm 0.6$ & $0.9 \pm 0.2$ \\
\hline Loam, silt ............ & $188 \pm 30$ & $22 \pm 4$ & $14 \pm 4$ & $17.2 \pm 2.8$ & $2.9 \pm 0.6$ & $0.7 \pm 0.2$ \\
\hline Coarser clay .......... & $234 \pm 31$ & $34 \pm 6$ & $21 \pm 4$ & $22.4 \pm 3.2$ & $3.4 \pm 0.7$ & $0.9 \pm 0.1$ \\
\hline Heavy clay .......... & $271 \pm 50$ & $95 \pm 20$ & $27 \pm 6$ & $35.8 \pm 5.4$ & $6.5 \pm 1.7$ & $1.0 \pm 0.2$ \\
\hline \multicolumn{7}{|l|}{ Deeper layers } \\
\hline Sand, fine sand .... & $42 \pm 10$ & $3 \pm 1$ & $5 \pm 2$ & $4.6 \pm 1.3$ & $0.5 \pm 0.2$ & $0.3 \pm 0.1$ \\
\hline Loam, silt ........... & $114 \pm 28$ & $32 \pm 10$ & $9 \pm 2$ & $9.1 \pm 1.3$ & $3.3 \pm 1.1$ & $0.4 \pm 0.1$ \\
\hline Coarser clay .......... & $191 \pm 27$ & $85 \pm 20$ & $16 \pm 3$ & $18.7 \pm 2.4$ & $6.2 \pm 1.5$ & $0.6 \pm 0.1$ \\
\hline Heavy clay .......... & $269 \pm 49$ & $167 \pm 32$ & $28 \pm 5$ & $29.2 \pm 4.3$ & $8.6 \pm 1.5$ & $0.9 \pm 0.1$ \\
\hline
\end{tabular}

According to results in Table 3 , the amounts of $\mathrm{Ca}$ and $\mathrm{Mg}$ dissolved by $0.1 \mathrm{~N} \mathrm{HCl}$ tend to be somewhat higher than the amounts in exchangeable form. In most cases, however, the difference between the corresponding mean values is not statistically significant. Only from the non-clay and coarser clay samples from the deeper layers, more $\mathrm{Ca}$ was extracted by this dilute acid than exchanged by $\mathrm{NH}_{4} \mathrm{OAc}$, and this is the case also with $\mathrm{Mg}$ in the clay soils from the deeper layers. Several samples gave somewhat lower amount of acid-soluble $\mathrm{K}$ than exchangeable $\mathrm{K}$, though because of the rather large variation, the difference between the corresponding average values is not statistically significant. 
Table 4. $\mathrm{Ca}, \mathrm{Mg}$, and $\mathrm{K}$ extracted by $1 \mathrm{n} \mathrm{HCl}$ at $50^{\circ} \mathrm{C}$

(Mean values with the confidence limits at 95 per cent level)

\begin{tabular}{|c|c|c|c|c|c|c|}
\hline & $\mathrm{Ca}$ & Mg & $\mathbf{K}$ & $\mathrm{Ca}$ & $\mathrm{Mg}$ & $\mathrm{K}$ \\
\hline & \multicolumn{3}{|c|}{$\mathrm{mg} / 100 \mathrm{~g}$} & \multicolumn{3}{|c|}{$\%$ of total } \\
\hline \multicolumn{7}{|c|}{ Surface soils } \\
\hline Sand, fine sand ... & $193 \pm 40$ & $243 \pm 49$ & $91 \pm 27$ & $17.8 \pm 3.5$ & $41.6 \pm 4.5$ & $5.1 \pm 1.2$ \\
\hline Loam, silt .......... & $207 \pm 33$ & $385 \pm 54$ & $149 \pm 31$ & $19.2 \pm 2.8$ & $49.5 \pm 3.2$ & $6.7 \pm 3.1$ \\
\hline Coarser clay ......... & $266 \pm 35$ & $504 \pm 60$ & $275 \pm 44$ & $25.1 \pm 3.2$ & $49.7 \pm 4.3$ & $11.2 \pm 1.8$ \\
\hline Heavy clay ....... & $297 \pm 50$ & $780 \pm 81$ & $366 \pm 72$ & $39.6 \pm 5.4$ & $52.1 \pm 5.2$ & $13.5 \pm 2.2$ \\
\hline \multicolumn{7}{|l|}{ Deeper layers } \\
\hline Sand, fine sand ... & $60 \pm 12$ & $214 \pm 16$ & $74 \pm 23$ & $5.7 \pm 1.1$ & $34.5 \pm 5.7$ & $5.1 \pm 1.1$ \\
\hline Loam, silt ........ & $142 \pm 29$ & $483 \pm 57$ & $237 \pm 48$ & $11.4 \pm 2.1$ & $45.6 \pm 4.3$ & $9.7 \pm 1.9$ \\
\hline Coarser clay ......... & $215 \pm 30$ & $721 \pm 57$ & $398 \pm 67$ & $18.9 \pm 2.5$ & $53.4 \pm 4.9$ & $14.0 \pm 2.1$ \\
\hline Heavy clay ....... & $309 \pm 52$ & $1129 \pm 96$ & $559 \pm 49$ & $33.8 \pm 3.1$ & $59.6 \pm 2.8$ & $18.1 \pm 1.4$ \\
\hline
\end{tabular}

Treatment of the soil samples with $\mathrm{N} \mathrm{HCl}$ at $50^{\circ}$ (Table 4) seems to dissolve $\mathrm{Mg}$ very effectively, but $\mathrm{Ca}$ to a not significantly higher extent than $0.1 \mathrm{~N} \mathrm{HCl}$ at room temperature. The average amounts of $\mathrm{Mg}$ released by the more drastic treatment are 7 to 18 times as high as those extracted by $0.1 \mathrm{~N} \mathrm{HCl}$, except in the sandy soils of deeper layers in which the corresponding ratio is 70 . The average amounts of $\mathrm{K}$ released by $\mathrm{N} \mathrm{HCl}$ at $50^{\circ}$ from the surface soils are 6 to 14 times and from the samples of deeper layers 15 to 25 times as high as those dissolved by the more diluted acid.

With increasing clay content there is a distinct tendency towards higher amounts of $\mathrm{Ca}, \mathrm{Mg}$ and $\mathrm{K}$ dissolved, though, particularly, the means of the relative release seem to differ between the adjacent groups less significantly. The part of total $\mathrm{Mg}$ released ranges from $3 \%$ to $60 \%$ in the sand and fine sand soils and from $40 \%$ to $70 \%$ in the samples of heavy clay. The corresponding limits for dissolution of $\mathrm{K}$ are $0.3 \%$ to $12 \%$ and $8 \%$ to $24 \%$, respectively, and for the release of $\mathrm{Ca} 3 \%$ to $37 \%$ and $25 \%$ to $53 \%$, respectively.

\section{Discussion}

The present results indicate that the total content of $\mathrm{Mg}$ in Finnish mineral soils seems to be fairly closely connected with the clay content of the soil. The same appears to be true also in respect to the occurrence of $\mathrm{K}$, though to somewhat lesser degree. The relative poorness of clay fraction in Ca observed in the previous paper (KAILA and RYTI 1968) is revealed in the lower average content of total $\mathrm{Ca}$ in the heavy clay soils than in the samples with less than $60 \%$ clay, and also in the low but statistically significant negative correlation between the $\mathrm{Ca}$ and clay contents of these soils. 
According to an old estimation (SEDERHolm 1925) the rocks of Finland contain averagely $2.4 \% \mathrm{Ca}, 1.0 \% \mathrm{Mg}$ and $3.0 \% \mathrm{~K}$. In these 210 soil samples analysed, the mean content of $\mathrm{Ca}$ was $1.1 \%$, of $\mathrm{Mg} 1.0 \%$, and of $\mathrm{K} 2.4 \%$. Even if allowance is paid to the fact that soils formed from basic rocks of northern Finland were not included in the present material, it seems that losses of $\mathrm{Ca}$ have been rather high during the relatively short age of these soils. Data collected by SOVERI (1956) of the chemical composition of our clay sediments show a higher mean content of $\mathrm{Ca}, 1.55 \%$, with the range from 0.8 to $2.8 \%$. Yet, it is likely that these results are from deeper layers of soils than those analysed in the present study, and therefore from less weathered material.

The $\mathrm{Mg}$ content of the surface layers of our mineral soils seems to be high as compared with data from many other parts of the world. In a German textbook (SCHEFFER and SchachtSchaBel 1970) the range of the usual total content of $\mathrm{Mg}$ is reported to be from $0.05 \%$ to $0.5 \%$, and according to JACKson (1956) the soils generally contain less than $0.6 \% \mathrm{Mg}$. In this material even the mean content of sand and fine sand soils was more than $0.5 \%$ and that in the heavy clay soils $1.5 \%$ in the surface samples.

Only a few per cent of total $\mathrm{Mg}$ was exchangeable and watersoluble, but, as an average, about one half could be released by $\mathrm{N} \mathrm{HCl}$ at $50^{\circ} \mathrm{C}$. Though it is supposed that $\mathrm{K}$ dissolved by this treatment would represent also the potentially available sources of $\mathrm{K}$ to plants (SснаснтSснABEL 1961), it is not likely that it is the case with $\mathrm{Mg}$. It is more likely and even proved by unpublished results of some pot experiments on exhaustive cropping, that an extraction with $0.1 \mathrm{~N} \mathrm{HCl}$ would give a more reliable estimation of the $\mathrm{Mg}$-sources of our soils than the more drastic treatment. The diluted acid dissolved from the surface soils $\mathrm{Mg}$ in amounts which were not, or only slightly, higher than the content of exchangeable $\mathrm{Mg}$ in the corresponding samples.

If the weight of the soil of the plough layer is taken to be $2500000 \mathrm{~kg}$, the average amount of $\mathrm{Mg}$ dissolved by $0.1 \mathrm{~N} \mathrm{HCl}$ would correspond to $350 \mathrm{~kg} / \mathrm{ha}$ in sand and fine sand soils, to $550 \mathrm{~kg} / \mathrm{ha}$ in loam and silt soils, to $850 \mathrm{~kg} / \mathrm{ha}$ in the coarser clay soils and to almost $2400 \mathrm{~kg} / \mathrm{ha}$ in the heavy clay soils. As compared with the annual uptake of about $10 \mathrm{~kg} \mathrm{Mg} / \mathrm{ha}$ by cereal crops, these sources seem to be fairly large. Yet, losses by leaching must be taken into account, and also the fact that there are sand and fine sand soils with less than 100 $\mathrm{kg} / \mathrm{ha}$, and loam and silt soils with no more than $150 \mathrm{~kg} / \mathrm{ha}$ of this "potentially available» Mg.

The sources of exchangeable $\mathrm{K}$ in the present soils would support cereal crops from 2 to $\mathbf{1 5}$ years. As far as the non-exchangeable part of the $\mathrm{K}$ extracted by $\mathrm{N} \mathrm{HCl}$ at $50^{\circ} \mathrm{C}$ would be released in the field rapidly enough, these sand and fine sand soils would supply $75 \mathrm{~kg} \mathrm{~K} / \mathrm{ha}$ for 10 to 90 years, loam and silt soils for 15 to 110 years, the coarser clay soils from 50 to 140 years and the heavy clay soils from 70 to 200 years. Leaching of $\mathrm{K}$ will, of course, cause losses, but on the other hand, the deeper layers may contribute, and their contents of both potentially plant-available $\mathrm{K}$ and $\mathrm{Mg}$ tend to be even higher than that of the more weathered and leached material of the surface layers.

It seems that $\mathrm{Ca}$ exists in our soils either as exchangeable and water-soluble ions or as part of the mineral lattice which is not dissolved by the acid treat- 
ments used. Exchangeable $\mathrm{Ca}$ in the surface samples of the present material would satisfy the annual $\mathrm{Ca}$ uptake of crops for about 100 years. This, however, does not mean that the indirect effect of Ca-ions on the conditions of our soils would be at an optimal state.

\title{
REFERENCES
}

JACKson, M. L. 1964. Chemical composition of soils. (In F. E. Bear: Chemistry of the soil: $41-171)$.

KaILA, A. \& RYTI, R. 1968. Calcium, magnesium and potassium in clay silt and fine sand fractions of some Finnish soils. J. Scient. Agric. Finl. 40: 1-13.

SснаснтsснавеL, O. 1961. Fixierung und Nachlieferung von Kalium- und Ammonium-Ionen. Landw. Forsch. 15. Sonderh.: 29-47.

Scheffer, F. \& Schachtschabet, P. 1970. Lehrbuch der Bodenkunde. 448 p. Stuttgart.

Sederholm, J. J. 1925. The average composition of the earth's crust in Finland. Bull. Comm. Géol. Finlande No 70, Helsinki.

SOVERI, U. 1956. The mineralogical composition of argillaceous sediments of Finland. Ann. Acad. Scient. Fennicae A III 48.

\section{SELOSTUS}

\section{Suomen eteläpuoliskon kivennäismaitten kalsiumista, magnesiumista ja kaliumista}

\author{
Armi KaIla \\ Yliopiston maanviljelyskemian laitos, Viikki
}

Tutkimuksessa on selvitetty 210 maanäytteer aineiston perusteella kivennäismaitten kalsiumin, magnesiumin ja kaliumin totaalipitoisuuksia sekä vaihtuvan, laimeaan kivennäishappoon liukenevan ja $1 \mathrm{n} \mathrm{HC1:n} 50^{\circ}$ :ssa vapauttaman kalsiumin, magnesiumin ja kaliumin osuuksia kokonaismäärästä. 